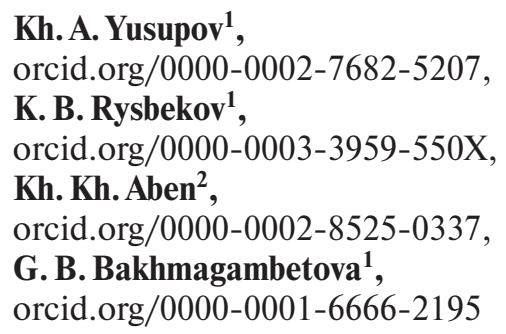

\title{
INCREASING GOLD LEACHING EFFICIENCY WITH CHANGE OF SOLUTION RHEOLOGICAL PROPERTIES
}

Purpose. Increasing the efficiency of gold heap leaching by changing the solution rheological properties due to its mechanical activation. Semi-industrial tests were carried out to verify the results of laboratory work.

Methodology. First, semi-industrial tests were carried out without activation of the solution (basic technology), and then the solution activation was applied. The ore amount in the stockpile was $600 \mathrm{~kg}$; the gold content in the ore is $1.12 \mathrm{~g} / \mathrm{t}$. At the same time, the concentration of cyanide was $400 \mathrm{ppm}$. The activation degree was from 3 to 8 minutes, the leaching time was $2,4,6$ hours, the solution temperature varied from 13 to 30 degrees.

Findings. According to the results of semi-industrial tests, the dependence of gold content, $\mathrm{pH}$ value, and residual concentration of the reagent on the leaching time was obtained using both proposed technology and the basic one. Comparison of the semiindustrial test results related to the basic technology and proposed one (with the solution activation) showed that the maximum gold content in the productive solution with the basic technology is $1.83 \mathrm{mg} / 1$, and with the activation of the solution it is $2.10 \mathrm{mg} / \mathrm{l}$. Hence, there is an increase in the gold content by $14.7 \%$ with the solution activation

Originality. Dependence of gold content in productive solution, $\mathrm{pH}$ value, and residual concentration of the reagent in solution on the degree of its activation has been obtained.

Practical value. The optimum degree of the treatment solution activation during gold heap leaching is determined, which is from 5 minutes to 7 minutes depending on the leaching time, which increases the gold content in the solution by $14.7 \%$.

Keywords: gold, heap leaching, cyanide concentration, mechanical activation, productive solution, leaching solution

Introduction. Mineral raw materials, which have more accurate porosity and permeability providing access of cyanide solutions to the surface of noble metals and diffusion of dissolved cyanide metal complexes into productive solution HL, are most suitable for processing by heap leaching (HL) method $[1,2]$.

In recent years, in the field of gold mining, work has been carried out to involve ores with a low initial content of useful components in processing. It is the heap leaching technology that is of particular interest for processing such raw materials [3].

The application of this process makes it possible to involve poor and out-of-balance ores in the production, open pit stripping soils, and mature fine tailings of processing plants. However, despite all the advantages, a significant disadvantage of such a leaching process was the low recovery rate, the duration of the leaching process, and the dependence on climatic conditions.

The analysis of the works on improving the efficiency of heap leaching makes it possible to draw the following conclusions:

- to intensify the leaching process, various types of effects on ore (physical, mechanical, chemical, biological ones) are used, most of which are aimed at accelerating the transfer of valuable components from ore to productive solution and improving its quality (maintenance);

- physical and mechanical intensification methods are mainly used when reducing the filtration properties of the rock, therefore, the choice of ore size, the method for laying and irrigation of the heap plays an important role;

- to increase the rate of metal dissolution, various catalysts ( $\mathrm{Fe}^{3+}$ ions, and so on) are introduced into the solution, which allows reducing the duration of heap leaching.

The works by many scientists are devoted to studying the influence of cyanide concentration on the intensity of metal leaching [4, 5]. The use of higher concentration solutions makes it possible to accelerate the leaching process, but at the

(C) Yusupov Kh.A., Rysbekov K. B., Aben Kh. Kh., Bakhmagambetova G. B., 2021 same time, the consumption is also increased due to its more intense interaction with some minerals [6].

The authors of [7], analyzing the results of further studies, conclude that for each concentration of $\mathrm{NaCN}$ the degree of gold recovery and its concentration in solution grow with increasing the number of irrigations to achieve a total of 40 $45 \%$ due to the extraction of gold from ore, while the consumption of sodium cyanide in general increases.

Meanwhile, studies are being carried out on the activation of pulp for intensification of cyanide-free leaching of fine-dispersed gold; in particular, preliminary electrohydraulic activation [8] is applied.

It follows from the work [9] that in the temperature range from 20 to $90{ }^{\circ} \mathrm{C}$ with an increase in temperature and duration, the degree of gold leaching by "aqua regia" from untreated and activated samples increases. However, activation of samples leads to an increase in the rate of gold extraction: $98 \%$ of gold are extracted in 20 minutes at $90{ }^{\circ} \mathrm{C}$, while the duration of gold extracting for untreated samples at the same temperature is 90 minutes [9].

To intensify the sorption cyanidation process, oxidation is proposed in two stages: physicochemical oxidation (based on directed photo-electro-chemical effects) and bio-oxidation.

Sulfide ores, including gold-pyrite, gold-mined ores, occupy a special place in refractory gold-bearing mineral raw materials (according to experts, the share of these ores is $30 \%$ of the world's gold reserves in the subsoil). In addition to the high dispersion of gold in such sulfides, the reasons for their technological persistence are also the presence of organic carbon. An analysis of mineral and raw material objects of gold ore deposits showed that ores of the black-shale formation of the stringer-porphyry mineralization type with fine-dispersed gold in sulfides and carbonaceous matter in the amount of $3-5 \%$ are of greatest interest.

When processing refractory raw materials with gold nanodroplets, the main causes of the valuable component loss include: 1) methods of mechanical disintegrating of the solid raw material matrix that does not allow grinding the material 
with a particle size of less than $0.001 \mathrm{~cm}$ and does not provide opening the gold micron inclusions; 2) hydrometallurgical and pyrometallurgical processes occurring at low redox potential, whose level does not provide oxidation of the floured part of the raw material matrix; 3) absorption of dissolved gold from the liquid phase of the pulp at standard cyanidation with clay minerals and carbonaceous substance activated during ore preparation without additional methods suppressing sorption properties of complexes.

The main problems of extracting ultrafine gold from ores concentrates, and fabricated raw materials using chemical processes are as follows: providing access to the valuable component of the leaching solution due to the formation of a sufficiently developed system of supply micro-cracks and pores in the carrier mineral crystals; the choice of an effective system of oxides and complexing agents that disturb the primary chemical bonds between gold atoms and mineral-forming atoms as well as form more stable bonds with it, compared to those elements to which it is associated initially but in the mineral matrix; providing the sequential and long-term output of gold into liquid phase due to various forms of its location, and accordingly, different conditions of its dissolution and precipitation of part of metal dissolved in the first minutes to mineralssorbents.

In this case, it is possible to improve the efficiency of ultrafine gold extraction by increasing the activity of oxygen, chlorine and hydrogen-containing complexes in solution (liquid phase). This is primarily related to the fact that the diffusion of the solution's active components deep into the mineral structure plays a decisive role in minerals with increased microfracture (capillarity) and porosity (layered micro-structure). Second, disruption of the bonds between the gold and the corresponding elements in the superfine layers of the sorbent minerals depends on the oxidizing capacity of the oxygencontaining free radicals. Thirdly, for example, montmorillonite activated during standard cyanidation, i.e. without additional complexes suppressing its sorption properties, can absorb already dissolved gold from the liquid phase of pulp [9].

Laboratory studies on the effect of activation before metal leaching prove the effectiveness of the proposed unconventional methods for opening the mineral matrix. The increase in gold extraction after the combined sulfide and arsenopyrite oxidation technology was $18 \%$, and the duration of bio-oxidation during the preliminary photo-electrochemical oxidation before leaching was reduced approximatively by 2 times $[10,11]$.

The efficiency of processing refractory gold-bearing raw materials by combined methods of cuvette and heap leaching based on directed photo electrochemical effects was experimentally confirmed due to the increase in through extraction of noble metals according to the material composition by $15.3-28.0 \%$.

The influence of photo-electrochemical effects on changing the material-structural parameters of the matrix of sulfide and sulfide-arsenide minerals, as well as on the rate of subsequent bio-oxidation was established with the formation of strong oxidizing agents (hydrogen peroxide and active oxygen species, chlorine-containing compounds). Results of twostage oxidation of minerals with disseminated gold were compared with the data obtained in experiments on bacterial oxidation without photo electrochemical actions. The following indicators increased significantly: the concentration of $\mathrm{Fe}^{3+}$ and arsenic in the liquid phase, the oxidation state of sulfides and sulfide sulfur, the rate of bio-oxidation. At the same time decrease in $\mathrm{pH}$ of pulp and increase in Eh of the productive solution was observed, the formation of new mineral phases was noted as well. It was experimentally confirmed that an increase in the dissolution rate of ultrafine gold was achieved by the use of two-stage oxidation based on the selection of effective oxidizing agents and activation methods. Rational parameters of photo-electrochemical effects were installed: duration of irradiation and bubbling with ozonized air, the voltage at electrodes in electrolysis cell, $\mathrm{NaCl}$ flowrate, and concentration of $\mathrm{H}_{2} \mathrm{SO}_{4}$.

It was found that the preparation of two-stage oxidation for leaching, both sulfides, and man-made raw materials leads to an increase in the extraction of metal into the liquid phase.

The processing of experimental data using mathematical statistics methods resulted in equations characterizing the dependence of the oxidation state of sulfide miners and sulfide sulfur on the values of the parameters of metallurgical properties. Based on experimental data obtained during laboratory studies on refractory mineral raw materials using two-stage oxidation before leaching, the empirical formula for the dependence of gold extraction on geological, mineralogical, and technological parameters was obtained [10].

However, despite the results, bio-oxidation is an expensive and extensible technology.

The most effective scheme turned out to be using a photoelectro-activated starting solution with subsequent injection of sodium cyanide into it, the reaction mixture injection into the pulp, and its electro-cavitation treatment. On average, despite the increase in gold recovered for ion exchange media in the amount of $72.3 \mathrm{~kg}(17 \%)$, obtained in experimental production lines, the development of the activation effect is heavy [12, 13]. The well-known cyanide technology by heap leaching (HL) also has several disadvantages: 1) low metal recovery (at the level of $50-80 \%$ ); 2) relatively long duration of the process (from 30 days to $1-2$ years); 3 ) the need for significant space; 4) negative impact of atmospheric phenomena and complexity of operation under harsh climatic conditions; 5) not all known types of goldbearing ores are suitable for cyanidation under HL conditions, and so on. That led to the idea of combining HL and cuvette leaching to take advantage of each other and reduce their disadvantages. However, the technology itself, even in combination, does not solve the problems of gold refractoriness [14].

The authors of works $[15,16]$ propose combination technology to increase the intensity of heap leaching. The essence of the given technology lies in the fact that after ore preparation processing of mineral mass by the solution of leaching reagent and extraction of gold are carried out in two stages: preliminary mineral mass is mixed in cuvettes with hydro-insulated walls and bottom, solution of initial reagent is introduced and local portion activation of obtained pulp (in this case, ozonized air) is carried out with the formation of secondary reagents at periodic removal of activated and introduction of inactive part of pulp into the activation zone. Further, the authors conducted studies to establish the effect of the leaching time of ore with a time-personal coarseness of grading on gold extraction. The results of the enlarged laboratory tests showed that an increase in the rise time from 1 to 6 hours leads to an increase in the extraction of gold from 20 to $65 \%$.

As the results of previous studies show, in order to increase the gold extraction during leaching, an increase in the cyanide concentration is necessary, which leads to an increase in the cost of leaching. One way to increase the rate of metal dissolution is to intensify the leaching properties of the solution, that is, intensify its activation.

To increase metal extraction without additional costs for leaching, a technique for changing the rheological properties of a working solution based on mechanical activation was proposed [17].

Activation of the leaching solution means the increase in the solution's chemical activity after its treatment in a cavitation plant. Due to the leaching solution activation, the transfer of both the useful component and the colmatage elements into the liquid phase increases, which reduces the likelihood of their precipitation in the form of colmatants. Cavitation in the liquid is accompanied by various chemical reactions. While some chemical reactions are accelerated, others are initiated. These reactions occur in an extremely short time [18].

Cavitation is the formation of fluid discontinuities as a result of local pressure reduction. The essence of cavitation tech- 
nology lies in the fact that leaching solution is cavitated before supply to ore mass. As a result of the mechanical effect (cavitation) on continuum, its structure and temperature change, which is accompanied by the breakdown of bonds between atoms and the destruction of the crystal lattice.

Technique. To determine the effect of the mechanical activation process on the efficiency of heap leaching, laboratory studies were carried out. Relationships between useful component content in the productive solution, the temperature of the product solution, the reaction time, the concentration of reactants in the leaching solution were obtained.

To prepare working reagents, $5 \mathrm{~g}$ of potassium iodide is dissolved in $100 \mathrm{ml}$ of distilled water. The obtained indicator is poured into a drip with a strained plug. $1.733 \mathrm{~g}$ of silver nitrate is dissolved in distilled water, poured into a measuring flask for $1000 \mathrm{ml}$, and brought to the mark with water. With a $10 \mathrm{ml}$ pipette, $10 \mathrm{ml}$ of productive or working solution is taken, poured into a $100 \mathrm{ml}$ conical flask, or into a $50 \mathrm{ml}$ beaker. Then 3-4 drops of potassium iodide solution are added. We titrate with a silver bath until the appearance of persistent yellowish turbidity.

A generator unit was prepared for the mechanical activation of the solution (Fig. 1). The generator is mounted on a platform, where a generator unit with inlet and outlet branch pipes and an electric motor are coaxially placed. Start and stop are performed by the activator control unit, to which the electric network is connected.

To establish the operability of the laboratory plant created for mechanical activation, test activations of liquids were carried out as follows: a working liquid was poured into the reservoir and an electric pump was turned on, which circulated the liquid through the generator along the MNC circuit. A change in the rheological properties of the liquids (solutions) used was recorded by measuring the mechanic-chemical parameters at certain intervals. The solution passing under pressure through the activator and returning to the container over time denatured rheological properties. There was no flow of solution through the docking units of the plant, which confirmed the tightness of the closed circuit.

When testing the laboratory installation, we detected that, when the solution drained after the experiments, part of it remained in the vertical pipe and was not removed due to the presence of a reverse valve. This is caused by design features of the used pump. Based on this experimental result, an electric pump with a drain plug was used. This allowed draining the next volume of cyanide solution into a separate tank completely each time after its treatment and washing the plant with water to prevent corrosion of the pump parts.

To perform treatment of the following volumes, a minimum of 1.5 liters of solution with the required concentration was poured into the container. It was determined that the preliminary stirring time was within 7-10 minutes to reach the test temperature.

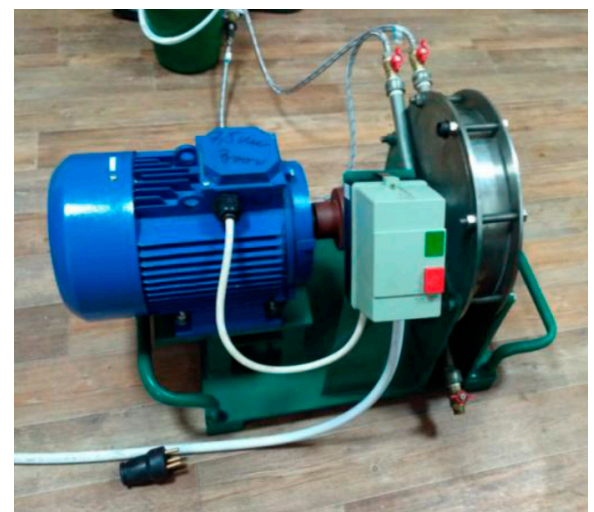

Fig. 1. Solution activation generator
Laboratory work was carried out with basic technology as well, i.e. without activation of the solution. During the testing the concentration of cyanide was $400 \mathrm{ppm}$ (a decrease in the cyanide concentration in the leaching solution with an increase in the activation degree is explained by an increase in the solution temperature). The activation rate altered from 3 to 8 minutes, the leaching time was 2, 4, 6 hours, the temperature of the cyanide varied from 13 to 30 degrees.

Research results. The laboratory results are summarized in Table 1 to select the optimal degree of the working solution activation.

As Table 1 shows, with an increase in activation extent from 3 to 7 minutes and at leaching time 2 hours the gold content in productive solution increases from 0.49 up to $0.64 \mathrm{mg} / \mathrm{l}$. Further increase in concentration degree, on the contrary, leads to a decrease in the content of gold in productive solution up to $0.6 \mathrm{mg} / \mathrm{l}$. The same change in the gold content of the production solution was observed at a reaction time of 4 and 6 hours. From the laboratory research it can be concluded that the optimal degree of the working solution activation ranges from 5 to 7 minutes depending on the leaching time.

Data processing of laboratory works gave dependences of gold content in productive solution on extent of leaching solution activation and leaching time (Fig. 2).

Table 1

Results of laboratory work in case of the leaching time change

\begin{tabular}{|c|c|c|c|c|}
\hline $\begin{array}{l}\text { Cavitation time, } \\
\text { minutes }\end{array}$ & $\begin{array}{c}\text { Gold } \\
\text { content, } \\
\mathrm{mg} / \mathrm{l}\end{array}$ & $\mathrm{pH}$ & $\begin{array}{l}t, \\
{ }^{t} \mathrm{C}\end{array}$ & $\begin{array}{l}C N, \\
\text { ppm }\end{array}$ \\
\hline \multicolumn{5}{|c|}{ with a leaching time of 2 hours } \\
\hline Without activation & 0.42 & 10.10 & 17.0 & 400 \\
\hline 3 & 0.49 & 10.09 & 20.2 & 350 \\
\hline 5 & 0.57 & 10.06 & 26.3 & 310 \\
\hline 7 & 0.64 & 10.02 & 27.5 & 285 \\
\hline 8 & 0.60 & 10.01 & 30.8 & 260 \\
\hline \multicolumn{5}{|c|}{ with a leaching time of 4 hours } \\
\hline Without activation & 0.56 & 10.12 & 17.0 & 400 \\
\hline 3 & 0.70 & 10.08 & 20.2 & 365 \\
\hline 5 & 0.79 & 10.05 & 26.3 & 325 \\
\hline 7 & 0.79 & 10.02 & 27.5 & 305 \\
\hline 8 & 0.80 & 10.00 & 30.8 & 280 \\
\hline \multicolumn{5}{|c|}{ with a leaching time of 6 hours } \\
\hline Without activation & 0.70 & 10.09 & 13.0 & 400 \\
\hline 3 & 0.72 & 10.08 & 15.0 & 340 \\
\hline 5 & 0.80 & 10.06 & 21.4 & 300 \\
\hline 7 & 0.76 & 10.05 & 23.5 & 280 \\
\hline 8 & 0.75 & 10.04 & 26.9 & 250 \\
\hline
\end{tabular}

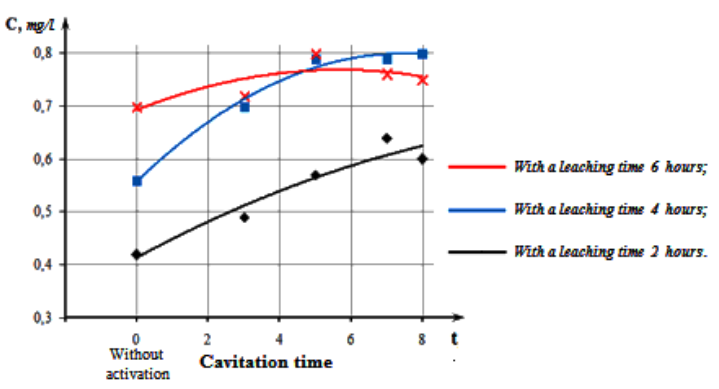

Fig. 2. Dependence of gold content in the productive solution on the degree of the alkaline solution activation and leaching time 
To verify the results of laboratory work, semi-industrial tests were carried out. Sampling was performed from freed ore in a quarry by an exhaustion method. There was about $1200 \mathrm{~kg}$ of ore in total.

Two technological types represented the ores: primary goldsulfide-quartz and oxidized. The results of group sample analyses showed that the concentration of harmful impurities is low in gold-bearing ores. The gold content of the ore is equal to $1.12 \mathrm{~g} / \mathrm{t}$.

For semi-industrial testing, a heap leach unit made of iron sheets was manufactured, which consists of a tray for the productive solution, the base of the plant, a container for the source solution, the main pipeline, and irrigation pipelines. The unit was installed in the laboratory.

To imitate the muck pile, a polyethylene film was glazed onto the plant. Semi-industrial tests were first carried out without solution activity (basic technology), then it was done with solution activity. The amount of ore in the pile was $600 \mathrm{~kg}$, the average gold content in the ore was $1.12 \mathrm{gr} / \mathrm{t}$, the cyanide concentration was $600 \mathrm{ppm}$, and activation degree was 5 minutes. The leaching time was 20 hours; the first sample was taken after 6 hours, further samples were taken every 2 hours.

Samples of the production solution after the tests were sent to the ore mine laboratory to determine the gold content, $\mathrm{pH}$ value, and residual reagent concentration.

Results of semi-industrial tests without activation of solution are given in Table 2.

As can be seen from Table 2, the gold content in the production solution increases from 0.3 to $1.83 \mathrm{mg} / \mathrm{l}$ with an increase in the leaching time from 6 to 16 hours. But the gold content in the production solution decreases to $1.43 \mathrm{mg} / \mathrm{l}$ with a further increase in the leaching time up to 20 hours. At the same time, the $\mathrm{pH}$ value is slightly reduced, and the residual concentration of the reagent decreases from 600 to $80 \mathrm{ppm}$.

Processing of semi-industrial testing data resulted in the dependence of gold content, $\mathrm{pH}$ value, and residual reagent concentration on leaching time at basic technology (Fig. 3).

Table 2

Results of semi-industrial tests without solution activation

\begin{tabular}{|c|c|c|c|}
\hline $\begin{array}{c}\text { Leaching time, } \\
\text { hour }\end{array}$ & $\begin{array}{c}\text { Gold content, } \\
\mathrm{mg} / \mathrm{l}\end{array}$ & $\begin{array}{c}\text { Residual reagent } \\
\text { concentration, } \\
\mathrm{ppm}\end{array}$ & $\begin{array}{c}\mathrm{pH} \\
\text { value }\end{array}$ \\
\hline 6 & 0.3 & 410 & 10.1 \\
\hline 8 & 0.59 & 310 & 10.1 \\
\hline 10 & 0.82 & 260 & 10.2 \\
\hline 12 & 1.34 & 215 & 10.2 \\
\hline 14 & 1.71 & 170 & 10.2 \\
\hline 16 & 1.83 & 135 & 9.7 \\
\hline 18 & 1.57 & 100 & 9.30 \\
\hline 20 & 1.43 & 80 & 9.1 \\
\hline
\end{tabular}

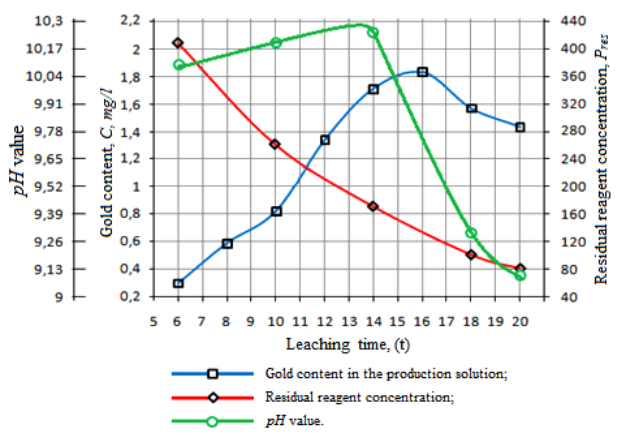

Fig. 3. Dependencies of gold content, $p H$ value, and residual reagent concentration on leaching time at basic technology
The results of semi-industrial tests with solution activation are given in Table 3 .

As can be seen from Tables 1,3, with an increase in leaching time from 6 hours to 16 hours, there is an increase in gold content in the production plant from 0.35 to $2.10 \mathrm{mg} / \mathrm{l}$. A further increase in the leaching time resulted in a reduction in the gold content of the production solution up to $1.65 \mathrm{mg} / \mathrm{L}$, with the residual reagent concentration decreasing from $600 \mathrm{ppm}$ in the initial solution to $120 \mathrm{ppm}$ at the end of the leaching.

Processing of semi-industrial testing data resulted in the dependence of gold content, $\mathrm{pH}$ value, and residual reagent concentration on leaching time at the basic technology (Fig. 4).

\section{Conclusions.}

1. Mechanical activation increases the activity of the working solution and reduces the time of crevice.

2. Dependence of gold content in productive solution on the degree of leaching solution activation and leaching time has been obtained. In particular, with an increase in the activation degree from 3 to 7 minutes and with a leaching time of 2 hours, the gold content in the production solution alters from 0.49 to $0.64 \mathrm{mg} / \mathrm{l}$. Further increase in the concentration degree vice versa leads to the gold content reduction in the production solution up to $0.6 \mathrm{mg} / \mathrm{l}$.

3. The maximum gold content of the product solution in the basic technology is 1.83 , and it is $2.10 \mathrm{mg} / \mathrm{l}$ when the solution is activated, i.e., there is an increase in the gold content when the solution is activated by $14.7 \%$.

4. The residual concentration of the reagent at the end of the semi-industrial tests in the production plant with the basic technology is 80 , and it is $120 \mathrm{ppm}$ when the solution is activated, i.e. when the solution is activated, the gold content in the solution is higher at lower specific consumption of the reagent.

Table 3

Results of semi-industrial tests with solution activation

\begin{tabular}{|c|c|c|c|}
\hline $\begin{array}{c}\text { Leaching time, } \\
\text { hour }\end{array}$ & $\begin{array}{c}\text { Gold content, } \\
\mathrm{mg} / \mathrm{l}\end{array}$ & $\begin{array}{c}\text { Residual reagent } \\
\text { concentration, } \\
\mathrm{ppm}\end{array}$ & $\begin{array}{c}\mathrm{pH} \\
\text { value }\end{array}$ \\
\hline 6 & 0.35 & 520 & 10.1 \\
\hline 8 & 0.68 & 390 & 10.2 \\
\hline 10 & 0.72 & 300 & 10.2 \\
\hline 12 & 1.55 & 240 & 10.25 \\
\hline 14 & 1.94 & 220 & 10.25 \\
\hline 16 & 2.10 & 180 & 9.90 \\
\hline 18 & 1.78 & 140 & 9.40 \\
\hline 20 & 1.65 & 120 & 9.35 \\
\hline
\end{tabular}

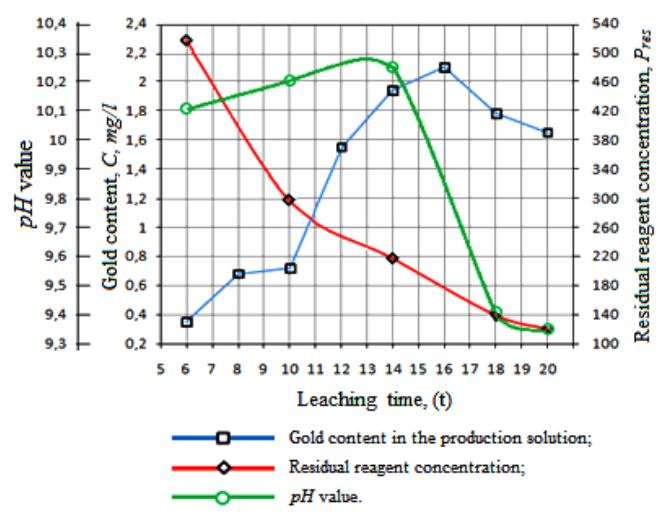

Fig. 4. Dependencies of gold content, $\mathrm{pH}$ value, and residual reagent concentration on leaching time when the solution is activated 
References.

1. Bocharov, V.A., Ignatkina, V.A., \& Kayumov, A. A. (2019). Theory and practice of minerals separation of massive persistent polymetallic ores of non-ferrous metals: monograph. Moscow: Publishing House: Gornaya kniga. ISBN: 978-5-98672-502-4.

2. Bitimbaev, M.Z., Oryngozhin, E.S., Nenashev, N.V., \& Musaev, E.L. (2014). Technological operations of gold intensive heap leaching of the Akzhal field. Collection of scientific works of MI named after D. A. Kunaev, 85, 26-29.

3. Yusupov, Kh., Rysbekov, K., \& Bakhmagambetova, G. (2020). Engineering of the site for heap leaching of gold. Pridneprovskiy Scientific Bulletin, 41(697), 1-3.

4. Egorova, I. V. (Ed.) (2019). Mining opportunities of subsoil: collective monograph. Moscow: FSBI "VIMS". ISBN 978-5-6042742-9-3.

5. Chanturia, V. A., Minenko, V. G., Samusev, A. L., Chanturia, E. L., \& Koporulina, E. V. (2017). Mechanism of combined energy effects on intensification of zirconium leaching and rare-earth elements from eudialite concentrate. Mineral enrichment. FTPRPI, (5), 105-112. https://doi.org/10.15372/FTPRPI20170512.

6. Lavrov, A.Y. (2015). Development of physical and chemical geotechnologies based on complex activation of mineral environment and work solution. ZabMU Bulletin, 6(121), 25-36.

7. Kanaev, A. T., Semenchenko, G. V., \& Kanaeva, Z. K. (2015). Influence of sodium cyanide concentration on the indication of percolation leaching of gold of the Bakyrchik deposit. International Journal of Applied and Basic Research, 2-2, 224-227.

8. Seredkin, M., Zabolotsky, A., \& Jeffress, G. (2016). In situ recovery, an alternative to conventional methods of mining: Exploration, resource estimation, environmental issues, project evaluation and economics. Ore Geology Reviews, 79, 500-514. https://doi. org/10.1016/i.oregeorev.2016.06.016.

9. Balikov, S.V., \& Dementyev, V.E. (2015). Gold: Properties. Geochemical aspects: monograph. OJSC Irkutsk Research Institute of Noble and Rare Metals and Diamonds OJSC Irgiredmet. ISBN: 978-5902324-08-9.

10. Shumilova, L.V. (2016). Preparation of pyrite-arsenopyrite concentrate for gold leaching based on use of polyreagent complexes. Mining sciences and technologies, (1). Enrichment and processing of mineral and technogene raw materials, (pp. 3-12). Retrieved from https://mst.misis.ru/jour/article/viewFile/12/14.

11. Sekisov, A. G., Myazin, V.P., Lavrov, A.Yu., \& Goncharov, D. S. (2016). Features of intracrystalline and interfacial diffusion processes in activation leaching of dispersed gold. GIAB, (1), 348-357. Retrieved from https://www.giab-online.ru/files/ Data/2016/1/348 357_1_2016.pdf.

12. Lavrov, A. Yu. (2013). Improving the development efficiency of ore deposits based on the use of innovative geotechnologies with photo electrochemical activation of technological schemes components. Bulletin of ZabMU, 02(93), 31-37.

13. Sekisov, A. G., Eremin, A. M., Lavrov, A. Yu., \& Konareva, T. G. (2014). Activation leaching of dispersed gold and its stage sorption and electrosorption from ore pulp and productive solutions. Rational development of subsoil, (3), 62-68.

14. Cherevko, S., Zeradjanin, A. R., \& Topalov, A. A. (2014). Effect of Temperature on Gold Dissolution in Acidic Media. Journal of the Electrochemical Society, 161(9), H501-H507. https://doi. org/10.1149/2.0551409jes.

15. Sekisov, A. G., Rubtsov, Yu. I., \& Lavrov, A. Yu. (2016). Activation heap leaching of dispersed gold from low-sulfide ores. Notes of the Mining Institute, 217, 96-101.

16. Yusupov, Kh. A., Aliyev, S., \& Dzhakupov, D. A. (2017). Examination of the ammonium bifluoride use for chemical treatment of wells. Mining Magazine, (4), 57-60. https://doi.org/10.17580/gzh.2017.04.11.
17. Aben, E. Kh., Rustemov, S.T., Bakhmagambetova, G.B., \& Akhmetkhanov, D. (2019). Increasing metal extraction based on activation of leaching solution. GIAB, (12), 169-179.

18. Chanturia, V.A., Shadrunova, I. V., Gorlova, O.E., \& Kolodezhnaya, E.V. (2020). Development of technological innovations in the deep and complex processing of technogene raw materials in the conditions of new economic challenges. TulSU bulletin. Earth sciences, (1), 159-171.

\section{Підвищення ефективності вилуговування золота зі зміною реологічних властивостей розчину}

\author{
Х. А. Юсупов ${ }^{1}$, К. Б. Рисбеков ${ }^{1}$, Х.Х. Абен ${ }^{2}$, \\ Г. Б. Бахмагамбетова ${ }^{1}$
}

1 - Satbayev University, м. Алмати, Республіка Казахстан, e-mail: k.yussupov@satbayev.university

2 - ТОО «КазМінералс», м. Алмати, Республіка Казахстан

Мета. Підвищення ефективності купного вилуговування золота шляхом зміни реологічних властивостей розчину за рахунок його механічної активації. Для перевірки результатів лабораторних робіт були проведені напівпромислові випробування.

Методика. Напівпромислові випробування спочатку були проведені без активації розчину (базова технологія), потім з активацією розчину. Кількість руди в навалі становила 600 кг, вміст золота в руді становить 1,12 г/т. При цьому концентрація ціаніду становила 400 ppm, ступінь активації від 3 до 8 хвилин, час вилуговування становив $2,4,6$ годин, температура розчину змінювалася від 13 до 30 градусів.

Результати. За результатами напівпромислових випробувань отримані залежності вмісту золота, величини pH і залишкової концентрації реагенту від часу вилуговування за базовою та пропонованою технологіями. Порівняння результатів напівпромислових випробувань базової та пропонованої технології (з активацією розчину) показало, що максимальний вміст золота у продуктивному розчині за базової технології становить 1,83 мг/л, а при активації розчину - 2,10 мг/л, тобто спостерігається підвищення вмісту золота при активації розчину на 14,7 \%.

Наукова новизна. Отримані залежності вмісту золота у продуктивному розчині, величини $\mathrm{pH}$ і залишкової концентрації реагенту в розчині від ступеня його активації.

Практична значимість. Визначено оптимальний ступінь активації робочого розчину при купному вилуговуванні золота, який становить від 5 до 7 хвилин залежно від часу вилуговування, що дозволило підвищити вміст золота в розчині на $14,7 \%$.

Ключові слова: золото, купне вилуговування, концентрація ціаніду, механічна активація, продуктивний розчин, вилуговуючий розчин

Recommended for publication by S. K. Moldabaev, Doctor of Technical Sciences. The manuscript was submitted 17.11.20. 